\title{
In vitro and in vivo anti-inflammatory activity of Dillenia pentagyna Roxb. bark, a folklore medicine of Mizoram
}

\author{
Zothanpuia $^{1 *}$, Bibhuti K. Kakoti ${ }^{2}$ \\ IDepartment of Pharmacy, Regional Institute of Paramedical and Nursing Sciences (RIPANS), Aizawl 796017, India \\ ${ }^{2}$ Department of Pharmaceutical Sciences, Dibrugarh University, Dibrugarh 786004, India
}

\begin{abstract}
Natural products have played an exceptionally important role in health care and prevention of diseases for thousands of years and are one of the greatest sources of medicine. Mizoram is a home to a rich variety of flora and fauna however; very less systematic survey and documentation were carried out to date. The plant diversity of Mizoram is not adequately studied as compared to other states of north east India. Dillenia pentagyna Roxb., known as kaihzawl in Mizo and dog teak in English, is one of the endangered plants that is yet to be explore. The Mizo communities use the decoction of $D$. pentagyna bark to treat different stomach ailments, inflammation and diabetes. In this perspective, the methanolic extract of the bark of $D$. pentagyna was evaluated for its anti-inflammatory properties. The extract showed the presence of flavanoids, triterpenoids, steroids, phenolics, saponins, fixed oils and others exerting varied pharmacological activities. The methanolic extract of this plant was found to contain active constituents such as betulinic acid and $\beta$-sitosterol which are found to actively interact with the inflammatory mediators and suppressed the inflammation when evaluated for its in vitro and in vivo anti-inflammatory activity. The present study suggests that the methanolic extract of $D$. pentagyna bark showed significant anti-inflammatory activity. This study also support the folkloric used of the plant in diseases related to inflammatory condition.
\end{abstract}

Key words: Anti-inflammatory; Anti-oxidant; Dillenia pentagyna; plant extract; Mizoram.

\section{Received 17 April 2017 Accepted 5 June 2017 \\ *For correspondence $\bowtie$ : zothan29@gmail.com}

\section{Introduction}

Mizoram is one of the eight states of North east India, situated in the extreme end of the Himalayan ranges covering 21,081 square $\mathrm{km}$ and lies between $92^{\circ} 15^{\prime}$ and $93^{\circ} 26^{\prime} \mathrm{E}$ longitude and $21^{\circ} 58^{\prime} 24^{\circ} 35^{\prime} \mathrm{N}$ latitude. ${ }^{1}$ The forests in Mizoram are the state's priceless possession forming a part of the Indo-Myanmar Biodiversity Hotspot. The ecosystem of Mizoram envelops a bewildering complexity in plant, animal and bird life. Mizoram is inhabited by various Mizo tribes using various herbal preparations for treating different ailments. These ethnic communities have a rich traditional knowledge and practicing traditional healing since time immemorial. ${ }^{2}$ With the increased knowledge of life and culture of the tribal communities, ethno-medicinal studies become a fascinating subject matter, and a large number of works from the rural and 
tribal communities of India have been reported, ${ }^{3}$ while studies on ethno-medicine and practices among the tribal communities in Northeast India are relatively less. ${ }^{4}$

Dillenia pentagyna Roxb. belongs to Dilleniaceae family, which is one of the most important traditionally used plant for treating wounds, arthritis, asthma, cancer etc in the tribal community of the Mizo. ${ }^{5}$ It is flourishing randomly in hilly areas of north-eastern states of India and Bangladesh. The stem bark of this plant has been used by the local people of Mizoram state, India, as a traditional medicine for the treatment of cancer suspected diseases, gastritis, asthma, dysentery and others, ${ }^{3,5}$ and the stem bark and fruit has also been reported to be used by other Indian ethnic communities as cure for blood dysentery, stomach pain and fistula. ${ }^{6}$

D. pentagyna has been screened for its antimicrobial, antioxidant potential and anti-cancer activities, and were found to be highly effective. $2,7,8$ Preliminary investigation with the methanolic extract of the dried bark of this plant was found to contain different phytochemical like flavanoids, triterpenoids, alkaloids, tannins and steroids; and was also found to possess a good antioxidant property when evaluated in vitro. ${ }^{9}$ We have also isolated betulinic acid and $\beta$ -sitosterol from this extract.

There is a growing interest in the pharmacological evaluation of various plants used in traditional systems of medicine owing to its virtual safety and popular belief as a safe alternative to synthetic medicines. ${ }^{10}$ The prime drawback at present existing potent synthetic drugs for the treatment of inflammation lies in their recurrence and toxicity of symptoms after discontinuation. For this reason the screening and development of drugs for their anti-inflammatory activity is still in progress and there is great anticipation for finding anti-inflammatory drugs from indigenous medicinal plants. The present study aimed at evaluating the antiinflammatory activity of the plant and to validate the traditional used of the plant for various inflammatory conditions.

\section{Materials and Methods}

\section{Plant material and preparation of the metha- nolic extract}

The bark of Dillenia pentagyna, commonly known as kaihzawl in Mizo and dog teak in English, was collected from Lailak village, a northeastern part of Mizoram, India. The barks were shade dried, sliced and pulverized using a mechanical grinder. The powdered materials were defatted by extracting with petroleum ether (at room temperature; $48 \mathrm{~h}$ ) using soxhlet apparatus. Thereafter, the extraction was carried out with methanol in the same manner as above. After exhaustive extraction, the methanolic extract was collected and concentrated under reduced pressure at $45-50^{\circ} \mathrm{C}$ to obtain the final product. The final product was then stored at $4^{\circ}$ C.

\section{Animals}

Adult Wistar rats weighing between 150-200 $\mathrm{g}$ and Swiss albino mice (weighing 20-25 g) of either sex were used in the experimental study. The animals were kept properly in polypropylene cages at $25 \pm 2^{\circ} \mathrm{C}$ (with $12 \mathrm{~h}$ light and dark cycle). The animals were provided free access to standard pellet diet and water ad libitum. The animals were acclimatized to laboratory environment for a week before the experiment. The care and use of laboratory animals were strictly in accordance to the guidelines prescribed by the Institutional Ethical Committee, RIPANS (constituted under the guidelines Committee for the Purpose of Control and Supervision of Experiments on Animals, India; Approval No. IAEC/ RIPANS/14, Dated $15^{\text {th }}$ May, 2013).

\section{Chemicals and drugs}

Carrageenin (80\% and 20\%); and lipopolysaccharide (LPS, E. coli: B4) were purchased from Sigma-Aldrich (St. Louis, MO, USA). All other unlabelled chemicals and reagents were of analytical grade (SRL Mumbai, Merck India). 


\section{Acute Inflammation}

Exudative inflammation: The methanolic extract of the plant (DPE), acetylsalicylic acid and control vehicle were administered to different group of animals and the protein content (using Bradford reagent) in the peritoneal exudates was determined for 3 hour following the intraperitoneal administration of $0.05 \mathrm{~N}$ acetic acid. ${ }^{11}$

Carrageenin-induced rat paw edema: Carrageenin (type $\mathrm{I} ; 0.1 \mathrm{ml}$ of $1 \%$ solution) was injected into the plantar aponeurosis of the right hind paw of the rats ${ }^{12}$ while the control vehicle or DPE or the standard drugs were fed orally 30 min prior to the injection of the carrageenin. The paw volume was measured just before and on hourly basis (up to 6 hour) following carrageenin administration using the volume displacement method..$^{13}$

\section{In vitro anti-inflammatory activity}

Effect on $\mathrm{PGE}_{2}$ production by COX-2 (whole blood assay): The freshly collected blood (heparinised) was incubated with acetylsalicylic acid $(12 \mathrm{~g} / \mathrm{ml})$ for $6 \mathrm{~h}$, followed by incubation at $37^{\circ} \mathrm{C}$ for $1 \mathrm{~h}$ with different concentrations of DPE or the standard drug (dexamethasone). Thereafter, $10 \mu$ l of LPS was added to the reaction mixture, and then the tubes were again incubated at $37^{\circ} \mathrm{C}$ for $24 \mathrm{~h}$. As a final point, the plasma was separated by centrifugation $(2000 \mathrm{rpm}$ for 10 min) and was used for the determination of $\mathrm{PGE}_{2}$ content according to the manufacturer's instruction (ELISA kit; GE Healthcare).

Effects on production of cytokines [interleukin-6 (IL-6) and tumour necrosis factor- $\alpha($ TNF- $\alpha)]$ : The mononuclear cells of human peripheral blood were prepared according to Yaqoob et al. ${ }^{14}$ The cells were suspended in culture medium (HEPES-buffered RPMI containing $2 \mathrm{mM}$ glutamine and antibiotics) and were incubated with either DPE or the standard drug $\left(6 \mathrm{~h}\right.$ at $\left.37^{\circ} \mathrm{C}\right)$ which is followed by stimulation with bacterial LPS. The medium was collected at the end of the incubation, and cytokines were analyzed by ELISA kit according to the manufacturer's instruction.

Table 1 | Effect of Dillenia pentagyna extract and nimesulide on acetic acid-induced peritoneal inflammation in mice (mean \pm S.E., $\mathrm{n}=6$ ) $P$ - value (versus control): ${ }^{*} P<0.05$, ${ }^{*} P<0.01$. [Doses of: $D$. pentagyna extract $\left(\mathrm{DPE}_{1}=400\right.$ $\mathrm{mg} / \mathrm{kg}, \mathrm{DPE}_{2}=800 \mathrm{mg} / \mathrm{kg}$;oral) and Nimesulide $\mathrm{N}=20 \mathrm{mg} / \mathrm{kg} ;$ i.p]

\begin{tabular}{|c|c|c|c|c|}
\hline \multirow{2}{*}{ Animal No } & \multicolumn{4}{|c|}{$\begin{array}{l}\text { Total amount of protein (mg) exudation } 3 \mathrm{hrs} \text { after administration of acetic acid } \\
\qquad(4 \mathrm{ml} \text { of } 0.05 \mathrm{~N} \text {; i.p.) }\end{array}$} \\
\hline & Control & $\mathrm{DPE}_{1}$ & $\mathrm{DPE}_{2}$ & $\mathbf{N}$ \\
\hline 1 & 12.73 & 6.35 & 6.74 & 6.88 \\
\hline 2 & 10.44 & 5.40 & 5.42 & 5.64 \\
\hline 3 & 16.48 & 7.25 & 5.61 & 1.73 \\
\hline 4 & 11.75 & 8.25 & 6.78 & 4.56 \\
\hline 5 & 12.73 & 13.5 & 4.85 & 2.55 \\
\hline 6 & 13.87 & 5.4 & 7.15 & 3.45 \\
\hline Mean \pm S.E. & $13.0 \pm 0.839$ & $8.22 \pm 1.246^{* *}$ & $6.12 \pm 0.369^{* *}$ & $4.13 \pm 0.790^{* *}$ \\
\hline Inhibition (\%) & - & 36.76 & 52.92 & 68.23 \\
\hline
\end{tabular}


Table 2 | Effect of Dillenia pentagyna extract and nimesulide on carrageenin-induced rat paw oedema (mean \pm S.E., $\mathrm{n}=6) P$ - value (versus control): $* P<0.05,{ }^{*} P<0.01$. [Doses of: $D$. pentagyna extract $\left(\mathrm{DPE}_{1}=400 \mathrm{mg} / \mathrm{kg}, \mathrm{DPE}_{2}=800\right.$ $\mathrm{mg} / \mathrm{kg}$;oral) and nimesulide $\mathrm{N}=20 \mathrm{mg} / \mathrm{kg}$; i.p]

\begin{tabular}{ccccccc}
\multirow{2}{*}{ Treatment } & \multicolumn{5}{c}{ Mean oedema volume $(\mathrm{ml})$ at different time intervals following carrageenin injection } \\
\cline { 2 - 7 } & ${1^{\text {st }}} \mathrm{hr}$ & $2^{\text {nd }} \mathrm{hr}$ & $3^{\text {rd }} \mathrm{hr}$ & $4^{\text {th }} \mathrm{hr}$ & $5^{\text {th }} \mathrm{hr}$ & $6^{\text {th }} \mathrm{hr}$ \\
\hline Control vehicle & $0.36 \pm 0.04$ & $0.52 \pm 0.02$ & $0.65 \pm 0.03$ & $0.67 \pm 0.01$ & $0.59 \pm 0.02$ & $0.56 \pm 0.01$ \\
$\mathrm{DPE}_{1}$ & $0.35 \pm 0.05$ & $0.45 \pm 0.03^{*}$ & $0.49 \pm 0.05^{* *}$ & $0.45 \pm 0.04^{*}$ & $0.37 \pm 0.02^{* *}$ & $0.37 \pm 0.03^{* *}$ \\
$\mathrm{DPE}_{2}$ & $0.15 \pm 0.03^{* *}$ & $0.23 \pm 0.04^{* *}$ & $0.15 \pm 0.02^{* *}$ & $0.09 \pm 0.04^{* *}$ & $0.07 \pm 0.03^{* *}$ & $0.06 \pm 0.02^{* *}$ \\
$\mathrm{~N}$ & $0.17 \pm 0.02^{* *}$ & $0.26 \pm 0.01^{* *}$ & $0.13 \pm 0.01^{* *}$ & $0.04 \pm 0.02^{* *}$ & $0.03 \pm 0.02^{*^{*}}$ & $0.03 \pm 0.01^{* *}$ \\
\hline
\end{tabular}

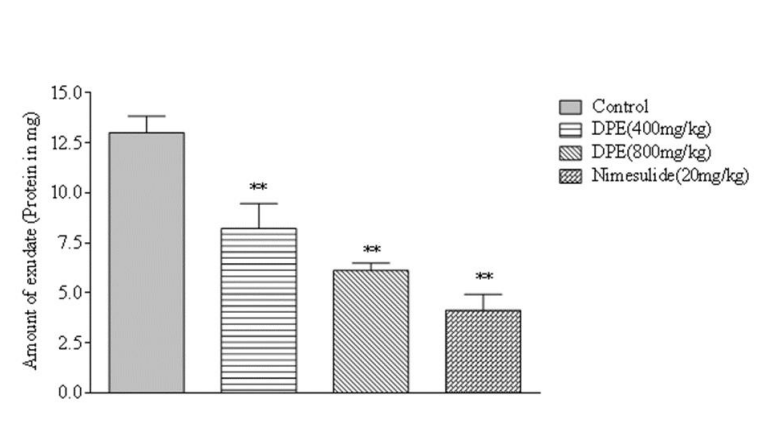

Figure 1 | Effect of Dillenia pentagyna extract (DPE) and nimesulide on acetic acid-induced exudative inflammation in mice (values are plotted as mean \pm SEM; $\mathrm{n}=6) P$ - value (versus control): ${ }^{*} P<0.05, * * P<0.01$

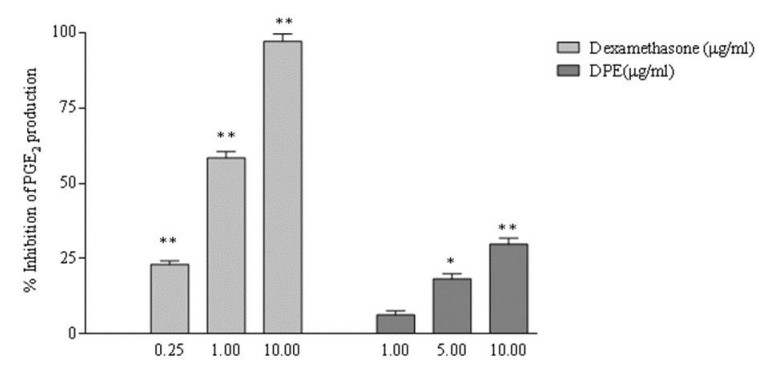

Figure 3 | Effect of Dillenia pentagyna extract (DPE) and dexamethasone on PGE2 production (Values are plotted as mean \pm SEM; $\mathrm{n}=6$ ) $P$ - value (versus control): ${ }^{*} P<0.05,{ }^{*} P<0.01$

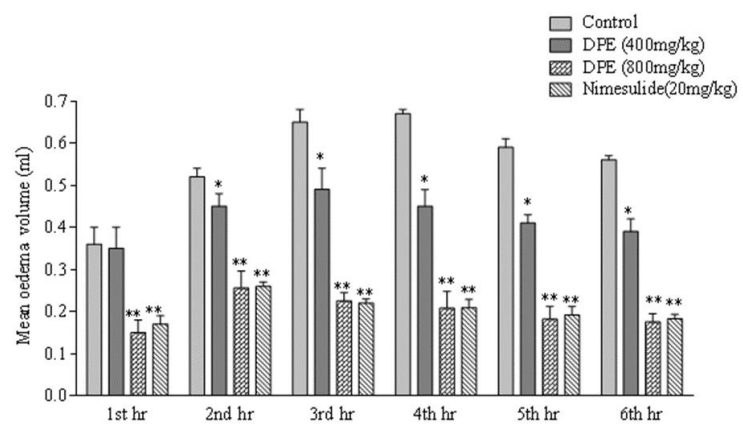

Figure 2 | Effect of Dillenia pentagyna extract (DPE) and nimesulide on carageenin-induced rat paw oedema (Values are plotted as mean \pm SEM; $\mathrm{n}=6$ ) $P$ - value (versus control): ${ }^{*} P<0.05,{ }^{*} P<0.01$

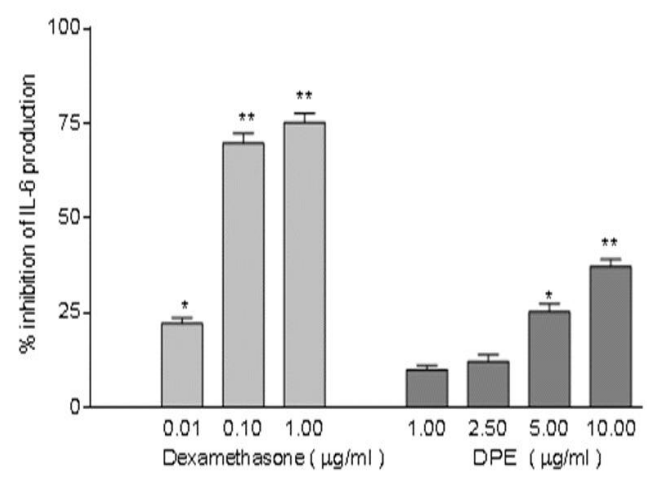

Figure 4 | Effect of Dillenia pentagyna extract (DPE) and dexamethasone on IL- 6 production (Values are plotted as mean $\pm \mathrm{SEM} ; \mathrm{n}=6) \quad P$ - value (versus control): $* P<0.05, * * P<0.01$ 


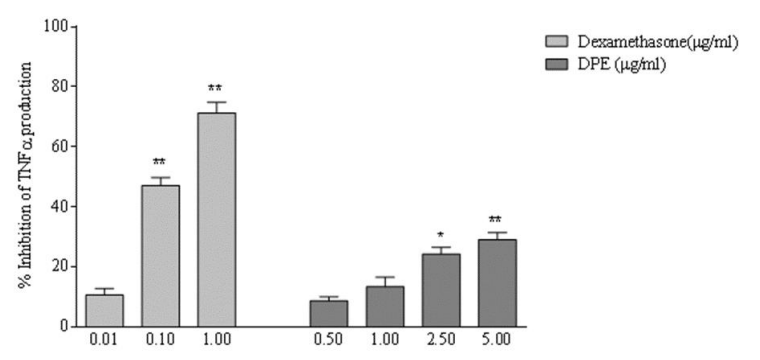

Figure 5 | Effect of Dillenia pentagyna Extract (DPE) and dexamethasone on TNF- $\alpha$ production (Values are plotted as mean \pm SEM; $\mathrm{n}=6) P$ - value (versus control): $* P<0.05, * * P<0.01$

\section{Result}

\section{Acute Inflammatory}

Exudative inflammation: Results of pretreatment with DPE $(400 \mathrm{mg} / \mathrm{kg}$ and $800 \mathrm{mg} / \mathrm{kg}$; oral) and nimesulide (20 mg/kg; i.p.) demonstrated significant $(P<0.01)$ inhibition $(30.48 \%$, $54.73 \%$ and $92.59 \%$ respectively) of acetic acidinduced peritoneal protein exudation (Table 1 and Fig. 1).

Carrageenin-induced rat paw oedema: $D$. pentagyna extract at a dose level of $400 \mathrm{mg} / \mathrm{kg}$ and $800 \mathrm{mg} / \mathrm{kg}$ significantly reduced both the early and late phases $(P<0.01)$ of carrageenininduced paw oedema. Nimesulide $(20 \mathrm{mg} / \mathrm{kg}$; oral) also exhibited similar significant response but to a greater extent (Table 2 and Fig. 2).

\section{In vitro anti-inflammatory activity}

Effect on $\mathrm{PGE}_{2}$ production by $\mathrm{COX}-2$ by whole blood assay: The methanolic extract of $D$. pentagyna bark extract and the standard drug significantly $(P<0.01)$ inhibited COX 2 dependent $\mathrm{PGE}_{2}$ generations in LPS-stimulated whole blood assays (Fig. 3).

Effect on production of cytokines [interleukin-6 (IL-6) and tumour necrosis factor- $\alpha($ TNF- $\alpha)]$ : The methanolic extract of D. pentagyna considerably inhibited the secretion of the pro-inflammatory cytokines in LPS stimulated mononuclear cells (Fig. 4 \& 5). D. pentagyna exhibited an $\mathrm{IC}_{50}$ of $88.64 \pm 6.3(\mathrm{~g} / \mathrm{ml}$ (IL-6) and $1.24 \pm 0.28(\mathrm{~g} / \mathrm{ml}$ (TNF- $\alpha)$, respectively. As evident from the $\mathrm{IC}_{50}$ values, dexamethasone was found to be more effective (IL-6, 39.41 $\pm 2.8(\mathrm{~g} / \mathrm{ml}$; TNF- $\alpha, 0.18 \pm 0.02 \mathrm{~g} / \mathrm{ml})$.

\section{Discussion}

Non-steroidal anti-inflammatory drugs (NSAIDs) are one of the most extensively used classes of drugs, with both over the counter and prescription sales of the agents contributing to total usage. NSAIDs are understood to act through inhibition of prostaglandin (PG) synthesis secondary to their inhibition of the enzyme cyclo-oxygenase (COX). This results in inhibition of inflammation, and effective analgesia. Majority NSAIDs not only inhibit PGs at sites of inflammation, but also PGs which provide important functions in other parts of the body, a factor which accounts for some toxic effects which is threat to the population. As a result, new approaches are deliberated with fewer side effects in comparison to the conventional drugs. In the present study, the anti-inflammatory activity of methanolic bark extract of $D$. pentagyna produced significant and also dose dependent inhibition of inflammation. The possible antiinflammatory activity may be due to its inhibition of cellular signaling pathways like NF-кB, which in turn have inhibition on the production of inflammatory cytokines like IL- 6 , TNF- $\alpha$, etc.

Carrageenin-induced rat paw oedema is the most common and recognized model. It is known to produce biphasic response, ${ }^{15}$ where the early phase is related to production of leukotrienes, histamines, PAF and possibly cyclooxygenase products, while the later phase is associated to the neutrophils infiltration, production of free radicals, eicosanoids release and release of other neutrophil derived mediators. ${ }^{16}$ The result of the study indicates that $D$. pentagyna and indomethacin plays a crucial role as protective factors against the carrageenin induced inflammation in a dose dependant man- 
ner.

Increased capillary permeability is one of the important consequences of inflammation leading to cellular infiltration coupled with protein exudation. In the present study the methanolic fraction of the plant extract showed significant inhibition against the peritoneal inflammation induced by acetic acid in the same way as nimesulide. Moreover, with the study of inflammatory mediators like $\mathrm{PGE}_{2}$, IL- 6 and $\mathrm{TNF}-\alpha$, the methanolic fraction of the plant produced significant inhibition of LPS-stimulated generation of those inflammatory mediators in a dose dependent manner.

The preliminary investigation of the methanolic fraction of this plant extract showed that it is rich in antioxidant phytochemicals and possessed a significant antioxidant potential when evaluated in vitro. Moreover have isolated betulinic acid and $\beta$-sitosterol, pharmacologically active phytoconstituents with multiple activities.

In response to inflammatory stimuli a wide array of reactive oxygen species (ROS) may also get unusually activated, which leads to inappropriate induction of various pro-inflammatory genes. ROS activate a number of intracellular signaling pathways, particularly those that are dependent on the transcription factors like NF$\kappa B$. NF- $k B$ has a ubiquitous presence and multiple functions in the body. However, the activation of NF- $k$ B by ROS is probably dependent on the nature of the stimulus and the cell type being studied. ${ }^{17}$ A variety of stimuli, including bacterial products, inflammatory cytokines, and oxidants have been found to activate the transcription factor NF- $k$ B. Once activated, NF- $k B$ translocates to the nucleus of the cell where it binds to consensus sequences on the promoterenhancer region of different genes, thereby activating the transcription of different genes predominantly associated with the immune and inflammatory responses. Recent studies have established the bridging role of $N F-k B$ between inflammation and cancer. ${ }^{18}$ NF-kB has been found to regulate the transcription of not only pro-inflammatory cytokines (IL-1 $\beta$, IL-2, IL-6, IL -8 , IL-12, TNF- $\alpha$ ), but also endothelial cell ad- hesion molecules such as intercellular adhesion molecule-1 (ICAM-1), vascular cell adhesion molecule1 (VCAM-1), E-selectin, mucosal adhesion cell adhesion molecule-1 (MAdCAM-1), as well as NOS (iNOS) and COX2. ${ }^{19}$ Thus, according to recent studies, the role of NF-kB activation is considered to be a crucial factor towards the management of chronic inflammation.

$\beta$-sitosterol, a phytosterol isolated from the extract is reported to possesses antioxidant, anti -inflammatory, anti-cancer and antihyperlipidemic activities ${ }^{20} \beta$-sitosterol inhibit both vascular adhesion and intracellular adhesion molecule 1 expression in TNF-alpha-stimulated HAEC. Moreover, this compound acts as an inhibitor on phosphorylation of $\mathrm{NF}_{k} \mathrm{~B}$. In fact, $\beta-$ sitosterol reduces the NF-kB transcription factor activity in macrophage cells. ${ }^{21} \beta$-sitosterol stimulates antioxidant enzymes by activation of estrogen receptor/PI3-kinase-dependent pathway. The GSH and GSH/total glutathione ratio recovered after treatment by $\beta$-sitosterol suggesting that this phytosterol could be a ROS scavenger. ${ }^{22}$

Another isolated compound from the methanolic extract of the plant is betulinic acid, pentacyclic triterpenoid, with numbers of pharmacological activities. There are reports of its anticancer activity, ${ }^{23-27}$ anti-HIV activity, ${ }^{28-30}$ antibacterial activity, ${ }^{31,32}$ anti-nociceptive activity, ${ }^{33}$ anti-inflammatory activity, ${ }^{34-40}$ and anti-ulcer activity $^{37}$. It is known that betulinic acid inhibits many important intracellular signaling pathways and inflammatory mediators like NF-k $\beta$, TNF- $\alpha$, COX-2 and interleukins. ${ }^{38,41}$

\section{Conclusion}

On the basis of the present findings we can suggest that the observed anti-inflammatory of Dillenia pentagyna may be attributed to its interaction with cellular signaling pathways like NF$k \mathrm{~B}$, which in turn have inhibition on the production of inflammatory cytokines like IL- 6 , TNF- $\alpha$, etc.

Present findings support the traditional claims and provide a scientific basis for antiinflammatory effect of D. pentagyna in disease of 
inflammation. This studies revealed that the plant has potential and favorable avenues for further studies to evaluate their medical value for chronic inflammatory conditions like ulcer, arthritis etc.

\section{References}

I. Sharma, H.K., Chhangte, L. \& Dolui, A.K. (20oI). Traditional medicinal plant in Mizoram India. Fitoterapia 72, I46-I6I.

2. Rosangkima, G., Rongpi, T. \& Prasad, S.B. (2010). Ethno-medicinal value of some anti-cancer medicinal plants from north-east India: an in vivo screening in murine tumor model. Science Vision 10, 123-132.

3. Lalramnghinglova, J.H. (1996). Ethnobotany of Mizoram - A preliminary survey. Journal of Economic and Taxonomic Botany 12, 439-459.

4. Lalmuanpuii, J., Rosangkima, G. \& Lamin, H. (2013). Ethno-medicinal practices among the Mizo ethnic group in Lunglei district Mizoram. Science Vision 13, 24-34.

5. Sawmliana, M. (2003). The book of Mizoram plants. P Zakhuma Aizawl, pp.58

6. Dubey, P.C., Sikarwar, R.L.S., Khanna, K.K. \& Arjun, P.T. (2009). Ethanobotany of Dillenia pentagyna Roxb. in Vindhya region of Madhya Pradesh India. Natural Product Radiance 8, 546-548.

7. Haque, M.E., Islam, M.N., Hossain, M., Mohamad, A.U., Karim, M.F. \& Rahman, M.A. (2008). Antimicrobial and cytotoxic activities of Dillenia pentagyna. Dhaka University Journal of Pharmaceutical Sciences 7, IO3-IO5.

8. Venkata, S.P., Mohan, C.M., Kandra, P., Sravani, R. \& Akondi, R.B. (2012). Screening of antimicrobial and antioxidant potentials of Acacia caesia, Dillenia pentagyna and Buchanania lanzan from Maredumilli Forest of India. Journal of Pharmacentical Research 5, I7341738 .

9. Zothanpuia, Lalawmpuii, P.C. \& Kakoti, B.B. (2014). Free radical scavenging activity and preliminary phytochemical screening of methanolic extract of the bark of Dillenia pentagyna Roxb. American Journal of Phytomedicine and Clinical Therapeutics 2, 910-918.

Io. Bent, S. (2008). Herbal Medicine in the United States: Review of Efficacy, Safety, and Regulation. Journal of
General Internal Medicine 23, 854-859.

II. Sen, T., Pal, S., Izzo, A.A., Capasso, F. \& Nag Chaudhuri, A.K. (1996). Studies on the methanolic fraction of the Pluchea indica on Croton oil-induced mouse ear oedema and lipid peroxidation. Pharmacy and Pharmacology Communications 2, 433-435.

I2. Winter, C.A., Risley, E.A. \& Nuss, G.W. (1962) Carrageenin induced oedema in hind paw of the rat as an assay for anti inflammatory drugs. Proceedings of the Society for Experimental Biology and Medicine III, 544547.

13. Bhatt, K.R., Mehta, R.K. \& Shrivastava, P.N. (1977). A simple method for recording anti inflammatory effects on rat paw oedema. Indian Journal of Physiology and Pharmacology 2I, 399-400.

I4. Yaqoob, P., Knapper, J.A., Webb, D.H., Williams, C.M., Newsholme, E.A. \& Calder, P.C. (1998). Effect of olive oil on immune function in middle age men. The American Journal of Clinical Nutrition 67, 129-135.

15. Vinegar, R., Scheriber, W. \& Hugo, R.J. (1969). Biphasic development of carrageenan edema in rats. Journal of Pharmacology and Experimental Therapeutics 166, 96-103.

16. Cuzzocrea, S., Zingarelli, B., Hake, P., Salzman, A.I. \& Szabo, C. (1998). Anti-inflammatory effects of mercaptoethylguanidine, a combined inhibitor of nitric oxide synthase and peroxynitrite scavenger in Carrageenan induced models of inflammation. Free Radical Biology and Medicine 24, 450-459.

17. Fink, M.P. (2002). Reactive oxygen species as mediators of organ dysfunction caused by sepsis, acute respiratory distress syndrome, or hemorrhagic shock; potential benefits of resuscitation with Ringer's ethyl pyruvate solution. Current Opinion in Clinical Nutrition and Metabolic Care 5, 167.

I8. Pikarsky, E., Porat, R.M., Stein, I., Abramovitch, R., Amit, S., Kasem, S., Gutkovich-Pyest, E., UrieliShoval, S., Galun, E. \& Ben-Neriah, Y. (2004). NFkappaB functions as a tumour promoter in inflammation-associated cancer. Nature 43I, 46I-466.

19. Pavlick, K.P., Laroux, F.S., Fuseler, J., Wolf, R.E., Gray, L., Hoffman, J. \& Grisham, M.B. (2002). Role of reactive metabolites of oxygen and nitrogen in inflammatory bowel disease. Free Radical Biology and Medicine $33,3 \mathrm{II}-322$. 
2o. Saeidnia, S., Manayi, A., Gohari, A.R. \& Abdollah, M. (20I4). The Story of Beta-sitosterol- A Review. European Journal of Medicinal Plants 4, 590-609.

2I. Loizou, S., Lekakis, I., Chrousos, G.P., \& Moutsatsou, P. (20I0). Beta-sitosterol exhibits anti-inflammatory activity in human aortic endothelial cells. Molecular Nutrition and Food Research 54, 551-558.

22. Vivancos, M. \& Moreno, J.J. (2005). Beta-Sitosterol modulates antioxidant enzyme response in RAW 264.7 macrophages. Free Radical Biology and Medicine 39, 9197.

23. Kumar, D., Mallick, S., Vedasiromoni, J.R. \& Pal, B.C. (20I0). Anti-leukemic activity of Dillenia indica L fruit extract and quantification of Betulinic acid by HPLC. Phytomedicine 17, 431-435.

24. Tezuka, Y., Stampoulis, P., Banskota, A.H., Awale, S., Tran, K.Q., Saiki, I. \& Kadota, S. (200o). Constituents of the Vietnamese medicinal plant Orthosiphon stamineus. Chemical and Pharmaceutical Bulletin 48, I7III7I4.

25. Liu, H., Wang, S., Cai, B. \& Yao, X. (2004). Anticancer activity of compounds isolated from Engelhardtia serrata stem bark. Archives of Physiology and Biochemistry 42, $475-477$.

26. Wada, S.I. \& Tanaka, R. (2005). Betulinic acid and its derivatives, potent DNA Topoisomerase II inhibitor, from the bark of Bischofia javanica. Chemistry and Biodiversity 2, 689-694.

27. Fu, L., Zhang, S., Li, N., Wang, J., Zhao, M., Sakai, J., Hasegawa, T., Mitsui, T., Kataoka, T., Oka, S., Kiuchi, M., Hirose, K. \& Ando, M. (2005). Three new triterpenes from Nerium oleander and biological activity of the isolated compounds. Journal of Natural Products 68, $198-206$.

28. Fujioka, T., Kashiwada, Y., Kilkuskie, R.E., Cosentino, L.M., Ballas, L.M., Jiang, J.B., Janzen, W.P., Chen, I.S. \& Lee, K.H. (1994). Anti-AIDS agents, Betulinic acid and Platanic acid as anti-HIV principles from Syzygium Claviflorum, and the anti-HIV activity of structurally related triterpenoids. Journal of Natural Products 57 , 243-247.

29. Theo, A., Masebe, T., Suzuki, Y., Kikuchi, H., Wada, S., Obi, C.L., Bessong, P.O., Usuzawa, M., Oshima, Y. \& Hattori, T. (2009). Peltophorum Africanum, a traditional South African medicinal plant, contains an anti
HIV-I constituent Betulinic acid. The Toboku Journal of Experimental Medicine 217, 93-99.

3o. Reutrakul, V., Chanakul, W., Pohmakotr, M., Jaipetch, T., Yoosook, C., Kasisit, J., Napaswat, C., Santisuk, T., Prabpai, S., Kongsaeree, P. \& Tuchinda, P. (2006). Anti -HIV-I constituents from leaves and twigs of Cratoxylum arborescens. Planta Medica 72, I433-I435.

3I. Woldemichael, G.M., Singh, M.P., Maiese, W.M. \& Timmermann, B.N.Z. (2003). Constituents of antibacterial extract of Caesalpinia paraguariensis Burk. Zeitschrift für Naturforschung C 58, 70-75.

32. Setzer, W.N., Setzer, M.C., Bates, R.B. \& Jackes, B.R. (200o). Biologically active triterpenoids of Syncarpia glomulifera bark extract from Paluma North Queensland Australia. Planta Medica 66, I76-177.

33. Krogh, R., Kroth, R., Berti, C., Madeira, A.O., Souza, M.M., Cechinel-Filho, V., Delle-Monache, F. \& Yunes, R.A. (1999). Isolation and identification of compounds with antinociceptive action from Ipomoea pes-caprae (L) R Br. Die Pharmazie 54, 464-466.

34. Recio, M.C., Giner, R.M., Manez, S., Gueho, J., Julien, H.R., Hostettmann, K. \& Rios, J.L. (1995). Investigations on the steroidal anti-inflammatory activity of triterpenoids from Diospyros leucomelas. Planta Medica 6I, 9-I2.

35. Costa, J.F.O., Barbosa-Filho, J.M., de Azevedo Maia, G.L., Guimarães, E.T., Meira, C.S., Ribeiro-dos-Santos, R., de Carvalho, L.C.P. \& Soares, M.B.P. (2014). Potent anti-inflammatory activity of betulinic acid treatment in a model of lethal endotoxemia. International Immunopharmacology 23, 469-474.

36. Tsai, J.C., Peng, W.H., Chiu, T.H., Lai, S.C. \& Lee, C.Y. (20II). Anti-inflammatory effects of Scoparia dulcis L. and betulinic acid. The American Journal of Chinese Medicine 39, 943-956.

37. Onwuchekwa, C. \& Oluwole, F.S. (2010). Anti-gastric ulcer and anti-gastric ulcer and anti-inflammatory properties of betulinic acid in male albino rats. The Scientific World Journal 5, I5-17.

38. Yun, Y., Han, S., Park, E., Yim, D., Lee, S., Lee, C., Cho, K. \& Kim, K. (2003). Immunomodulatory activity of betulinic acid by producing pro-inflammatory cytokines and activation of macrophages. Archives of Pharmacal Research 26, 1087-1095.

39. Patocka, P. (2003). Biologically active pentacyclic triter- 
penes and their current medicine signification. Journal of Applied Biomedicine I, 7-I2.

40. Viji, V., Helen, A. \& Luxmi, V.R. (20II). Betulinic acid inhibits endotoxin-stimulated phosphorylation cascade and pro-inflammatory prostaglandin $\mathrm{E}_{2}$ production in human peripheral blood mononuclear cells. British Journal of Pharmacology 162, I291-1303.
4I. Huang, M.T., Badmaev, V., Ding, Y., Liu, Y., Xie, J.G. \& Ho, C.T. (200o). Anti-tumor and anti-carcinogenic activities of triterpenoid beta-boswellic acid. BioFactors I3, 225-230. 